\title{
Utilization of the Internet as a Media Promotion Marketing
}

\author{
S Wiganepdo ${ }^{1}$, T Setiani ${ }^{2}$ \\ \{ swiganepdo@email.unikom.ac.id $^{1}$, tiasetiani97@ mahasiswa.unikom.ac.id $^{2}$ \} \\ Departemen Keuangan dan Perbankan, Universitas Komputer Indonesia, Indonesia ${ }^{1}$ \\ Fakultas Teknik dan Ilmu Komputer, Universitas Komputer Indonesia, Indonesia ${ }^{2}$
}

\begin{abstract}
The purpose of this research is to implement the Internet as a medium for promotional marketing of products. The method used in this research is a descriptive method with a qualitative approach. The results of this research are product marketing by utilizing internet media and advertising their products on the Internet so they can do marketing quickly. This research is done by knowing various ways to promote or market the product through social media. The conclusion of this study is the existence of Internet media has great benefits compared to conventional way as it can reduce the amount of cost and time spent in the product sales process.
\end{abstract}

Keywords : Utilization, Internet, Marketing

\section{Introduction}

Nowadays, the Internet and users have developed rapidly. The development is supported by the increasing number of Internet users in Indonesia [1]. The usage of Internet for promotion is usually called Internet Marketing. Internet Marketing is a way to promote a product or service offered by a company that runs a business on the Internet. Also, one can also create social media accounts or blogs to use as a tool for introducing products or services. The usage of the Internet in business is growing, from exchanging information electronically to business strategy applications such as marketing, sales and customer service [2]. Advances in technology that happens very quickly have encouraged companies to implement new marketing and business practices. The Internet as part of technological advances has reestablished the market and business dramatically [3]. Social Media is used as a marketing communication tool following the marketing and target programs. Several outcomes can be generated through social media marketing which includes increased brand popularity, reputation, relationships, intention of purchase, and brand development [4]. Social Media is the main weapon capable of providing exclusive offers so that consumers can feel privileged and demonstrated through expressions of gratitude through purchase. Social Media is a tool to increase sales and measure the range of all sales promotions that have been made [5]. Social Media essentially changes the way we communicate, collaborate, consume, and create. They represent one of the most transformative impacts of information technology on business both inside and outside the company's boundaries [6]. The success of the company depends on the ability to implement marketing 
functions while the marketing department acts as an important department as it is a business function directly interact with the consumers [7].

Entrepreneurs, especially marketers realize that they cannot rely on traditional marketing. To increase sales volume, employers should be able to implement an advertising program i.e. Internet with online marketing [8]. According to Dr. Ir. Eddy Soeryanto Soegoto in his book titled "Become the Master of Business" 2014, a newly established company must be published in advance so that it is known by the public, as well as the products that have launched recently. The publication can be done directly through promotion or indirectly through quality products or services so that it becomes a mouth talk by consumers. Promotion must be done by every company whether it is newly established or old. By utilizing social media to promote the products, it can be an alternative way of assisting the marketing process of local products. The following main models of communication tools in the promotion mix include (1) Advertising, (2) Sales promotions, (3) Direct marketing, (4) Public relations, and (5) Social media [9]. Product marketing can also be done with ads that must be determined based on a previous agreement on the target market, market position, and marketing mix. Advertisers have already acknowledged that they should adapt their marketing plan to continue pursuing the increasing number of people who spend time in front of the computer [10]. The study aimed to know how to market the products by using Internet media in the online business world in order to facilitate the sales process.

\section{Material and Methods}

This research used the descriptive method with a qualitative approach. Data collection techniques used were observation in which data are collected systematically about events or facts. This research attempts to evaluate systematically, factually and accurately about the facts in the use of the internet as an online media business in marketing by focusing on several internet methods that are applied and the communication process that takes place through internet media.

\section{Results and Discussion}

The Internet makes it easy for shoppers to know what products sellers have to offer, the sellers try to renew their products by looking at the outside product design as inspiration and giving them ideas. Today is the internet era. Therefore, almost every type of business someone does will cross with the Internet, including promotions. The presence of social media supported by the power of today's internet has the potential to support successful sales of businesses or products with cheap, fast, and ease even without spending money at all. The various features available on the Internet such as websites, blogs, and social media make the internet practical in making a person's business promotion activities more optimal. The following is a variety of ways to promote product marketing through social media:

The smallest scope we can maintain to market your product or service is the closest friend, it is perfect for those who are friends with you in chat messenger such as WhatsApp, BBM, line. You can immediately provide product and image data, as well as direct communication about the details, from the discounted price to the type of courier to be selected for shipping (Fig. 1). 


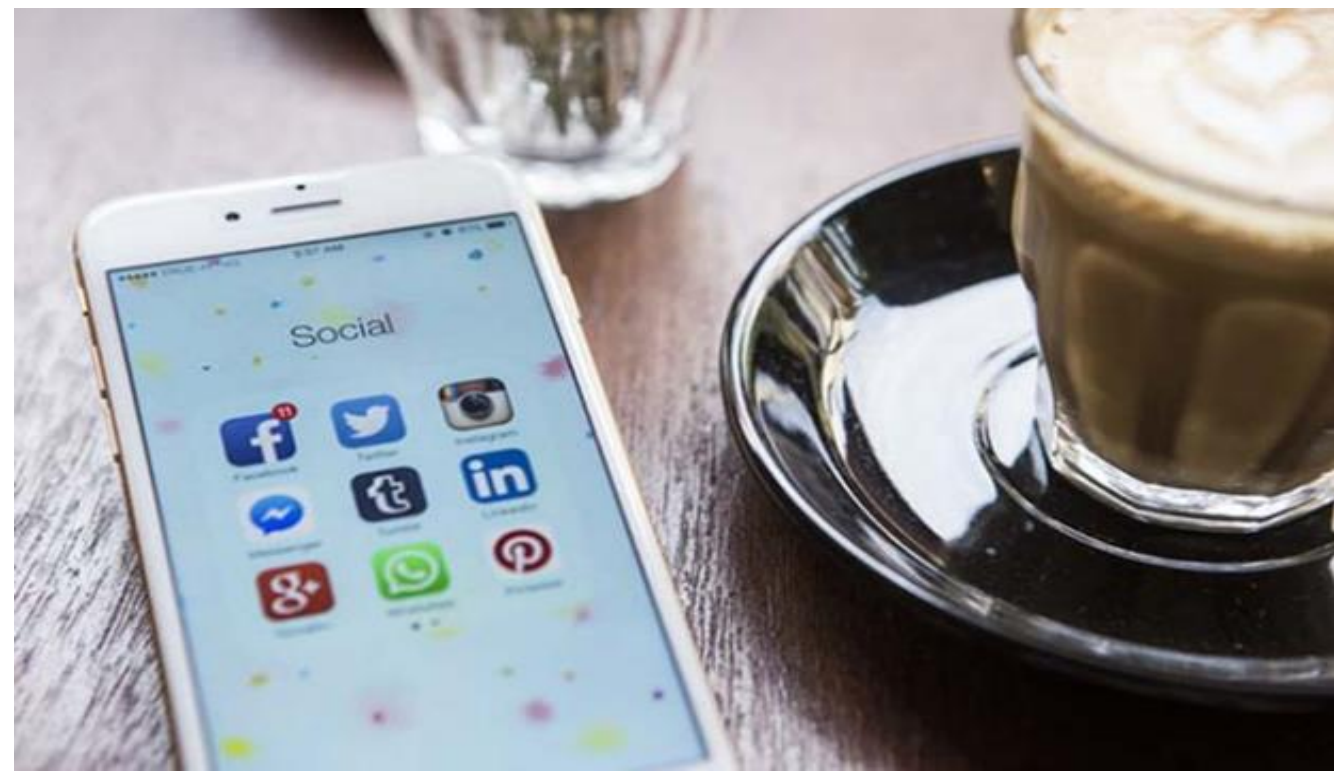

Fig 1. Communication Via Messenger Group.

Facebook can be the main social media of your choice to market your product online. Through Facebook, you can share posts, images, videos, or link sites. (Figure 2)

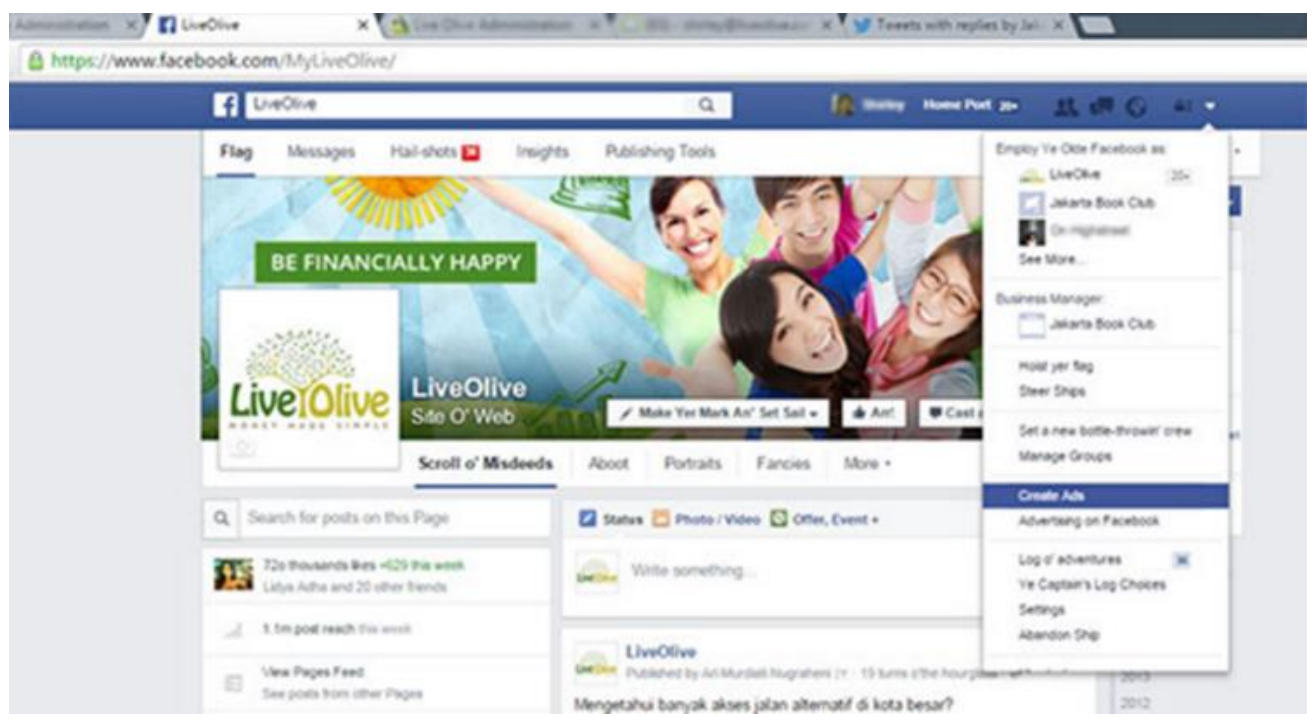

Fig 2. Facebook Display Page. The figure was adopted from www.facebook.com . On Dec 10th,2018.

This social media can use a "board" system to store interesting things, where users can share content based on certain categories of products or services offered. Since most Pinterest users 
come from abroad, if you can optimize this social media, it is not impossible that your business can be more popular (Figure 3).

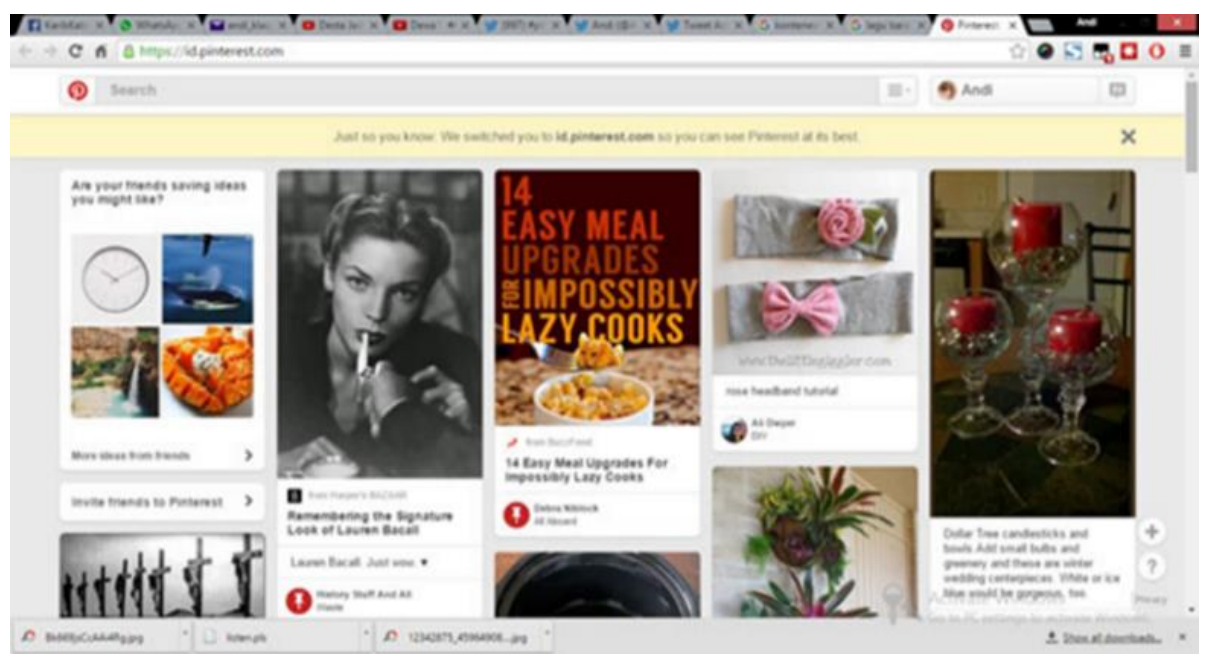

Fig 3. Pinterest. Figure was adopted from www.pinterest.com . On Dec 10th,2018.

Not only through personal websites or blogs, but online business owners can also advertise their products in the marketplace, which is a type of portal that provides opportunities for product entrepreneurs to do promotions for free by having their own online store page. Some well-known online marketplaces in Indonesia are Tokopedia, Bukalapak, OLX, Blibli, Lazada, and so on. (Figure 4)

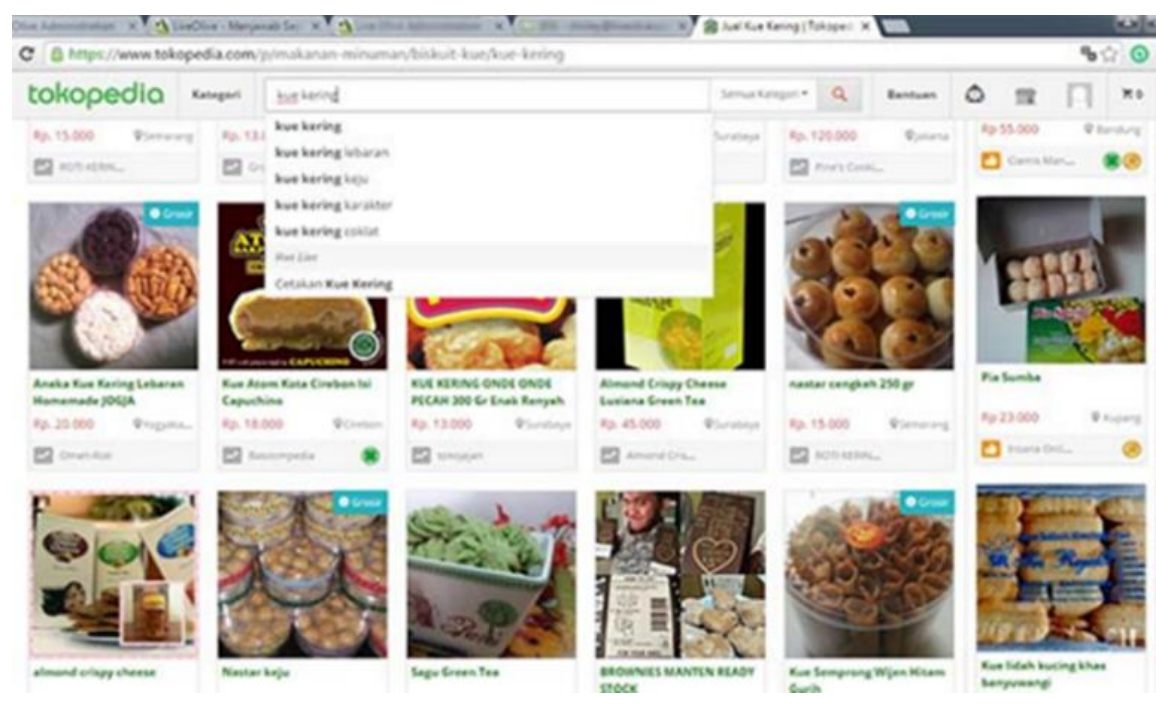

Fig 4. MarketPlace-site buying and selling. Figure was adopted from www.tokopedia.com . On Dec 10 th, 2018 
This free feature provided by Google will increase the likelihood that your product can be found by internet users. By registering on Google My Business, your business will appear in the list of top location-based searches. Google My Business is an updated version of Google Places. (Figure 5)

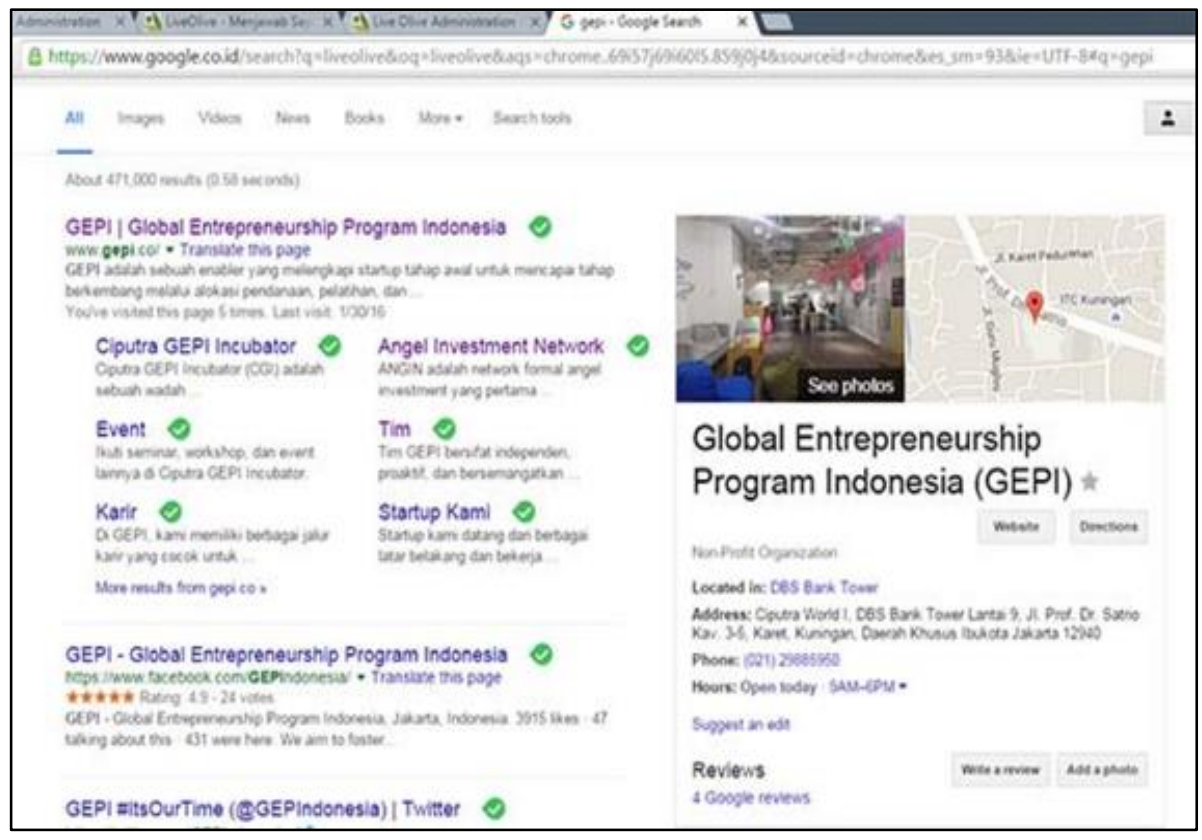

Fig 5. Google My Business. Figure was adopted from www.google.com . On Dec 10th,2018.

\section{Conclusion}

This study concludes that the use of internet is expected to provide great benefits in the competitive business world. Information technology in the form of the internet can be very effective marketing of products through social media. With the existence of internet, the seller has larger benefits by using internet media compared to conventional means because it can reduce the number of costs and time spent in the product sales process.

\section{References}

[1] Irmawati, D. :Pemanfaatan e-commerce dalam dunia bisnis. Jurnal Ilmiah Orasi Bisnis-ISSN, 2085, 1375. (2011).

[2] Yuliana, O. : Penggunaan Teknologi Internet dalam Bisnis. Jurnal Akuntansi dan Keuangan, 2(1), 36-52. (2004).

[3] Dharmmesta, Basu Swastha.: "Manajemen pemasaran." 1-38. (2014).

[4] Moriansyah, L. Pemasaran melalui Media Sosial: Antecedents dan Consequences. Jurnal Penelitian Komunikasi dan Opini Publik, 19(3). (2015).

[5] Poetra, R. R., \& Christantyawati, N. :Model AIDA: Pola Penggunaan Media Sosial dalam Meningkatkan Kepuasan penjualan online. Jurnal Komunikasi Profesional, 1(1). (2017). 
[6] Aral, S., Dellarocas, C., \& Godes, D. : Introduction to the special issue - social media and business transformation: a framework for research. Information Systems Research, 24(1), 3-13. (2013).

[7] Basu Swastha. "Manajemen pemasaran." (2014)

[8] Wandanaya, A. B. : Pengaruh Pemasaran Online Terhadap Keputusan Pembelian Produk. CCIT Journal, 5(2), 174-185. (2012).

[9] Soegoto, Eddy Soeryanto. : Enterpreneurship Menjadi Pembisnis Ulung. PT Elex Media Komputindo. Jakarta: KOMPAS GRAMEDIA. 2014.

[10] Maulina, D.: E-Commerce Sebagai Pendukung Pemasaran Perusahaan. Yogyakarta: STMIK AMIKOM Yogyakarta. (2004). 